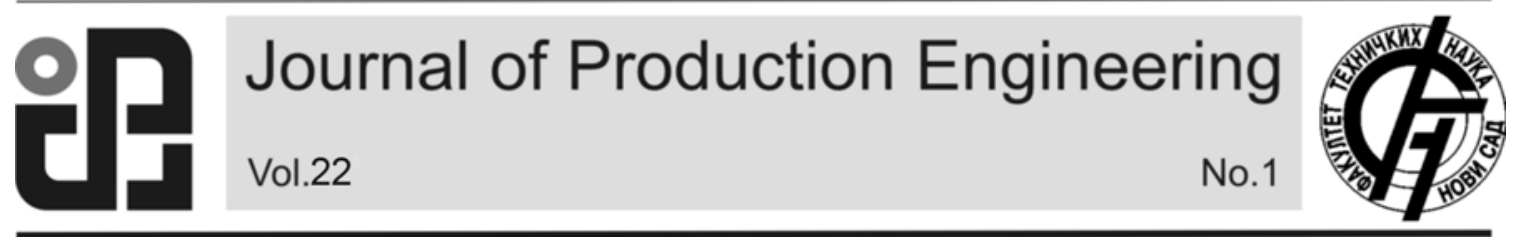

JPE (2019) Vol.22 (1)

Jain, A., Bansal, P., Khanna, P

Preliminary Note

\title{
DEVELOPMENT OF A MATHEMATICAL MODEL TO PREDICT THE EFFECT OF INPUT PARAMETERS ON TABLET FEEDING RATE OF A VIBRATORY BOWL FEEDER
}

\author{
Received: 14 January 2019 / Accepted: 25 April 2019
}

\begin{abstract}
Rapid industrialization and technological advancements in assembly processes and the demand for feeding the components in assembly lines has grown significantly. It, therefore, becomes essential to optimize the assembly process. Automated or mechanized assembly can be achieved by the use of feeders. This paper describes the mathematical modelling and performance analysis of a vibratory bowl feeder for feeding of medicinal tablets by using design of experiment technique where the adequacy of model was tested by analysis of variance (ANOVA) and significance of regression coefficients is checked by using t-tests. The mathematical model so developed would prove to be useful to establish quantitative relationship between the response parameter and the process parameters like frequency, part population and part size.
\end{abstract}

Key words: mechanized assembly, design of experiments, ANOVA, mathematical model.

Razvoj matematičkog modela za predviđanje efekata ulaznih parametara vibrirajućeg dozatora pri doziranju delova u obliku tableta. Brza industrijalizacija i tehnološki napredak u procesima montaže i potražnja za doziranjem komponenti u montažnim trakama značajno je porasla. To, dakle, postaje bitno za optimizaciju procesa montaže. Automatizovano ili mehanizovano sklapanje može se postići korišćenjem dozatora. Ovaj rad opisuje matematičko modeliranje i analizu performansi vibracione posuda za doziranje medicinskih tableta pomoću faktornog plana eksperimenta gde je adekvatnost modela testirana analizom varijance (ANOVA) i značajnost regresionih koeficijenata se proverava pomoću t-testa. Tako razvijeni matematički model pokazao bi se korisnim za uspostavljanje kvantitativne veze između izlaznih parametara i ulaznih parametara kao što su frekvencija, populacija dijelova $i$ veličina dijela.

Ključne reči: automatizovana montaža, fatkorni plan eksperimenta, ANOVA, matematički model.

\section{INTRODUCTION}

With modern day industries moving towards automation to increase their rate of production, automated feeding of parts has become an important process for them [1]. In automated assembly systems, part feeders play a very important role as they are responsible for supplying the machine continuously segregated parts at a specific flow rate and orientation. In such automated feeder systems part feed rate is as important as the orientation because at the point of assembly the critical requirement is that the part must be available in the correct orientation that further necessitates designing of a special delivery chute which is part geometry specific. Part feeders are used to orient and deliver parts like nuts, bolts, capsules, tablets, pins and other small components at a specific feed rate and to desired locations usually on a conveyer belt or machine [2].

\subsection{General requirements of part feeders:}

The following are some of the general considerations that must be followed while designing a part feeder.

1. In a mechanized assembly, the output of parts from the feeder is always restricted by the machine being fed. The machine will generally use parts at a strictly uniform rate and this may be referred to as the machine rate. In the design and testing of part feeders, it is often convenient to observe the feed rate when the feeder is not connected to a machine. The feed rate under this circumstance is referred to as the unrestricted feed rate which must be greater than the machine rate [3].

2. With part feeders suitable for automatic machines it is necessary that all the parts be presented to the machine in the same orientation. Some feeders are able to feed and orient many types of parts whilst others are only able to handle a very limited range of part shapes.

3. A part feeder should be reliable i.e. it should be designed so that the possibility of parts jamming in the feeder is minimised or eliminated.

4. Some part feeders are noisy in operation and some tend to damage certain types of parts [4].

\section{MATERIALS AND METHODS}

\subsection{Experimental Setup}

The setup consists of a vibratory bowl feeder where the components to be fed, in this case tablets, are placed in a bowl in a random fashion. A feed track is used to move the components from the bowl to the location of packaging maintaining proper orientation of parts during the transfer. The bowl feeder is vibrated at desired frequency making the tablets to ascend a spiral 
track attached to the internal face of the bowl wall in a particular orientation which is lateral in this case. The spiral track leads the tablets to the delivery chute at a feed rate which is the subject of investigation in present case [5].

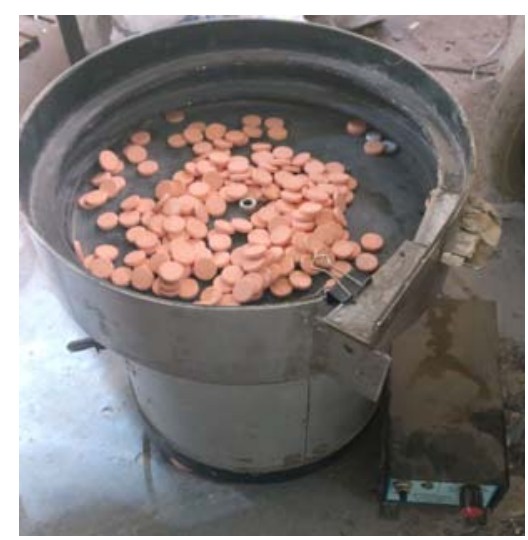

Fig. 1. Vibratory bowl feeder

\subsection{Identification of Input Parameters and establishing their operating ranges}

A series of trial runs were conducted to check the effect of various input parameters on the feed rate and it was found that, following individually controllable three input parameters (Table 1) had the most significant effect on feed rate. The operating ranges of these parameters are also mentioned. The high level of parameters are coded as $(+1)$, whereas the low value is coded as (-1).

\begin{tabular}{|c|c|c|c|c|}
\hline Factor & Name & Units & $\begin{array}{c}\text { High } \\
\text { Level } \\
(+1)\end{array}$ & $\begin{array}{c}\text { Low } \\
\text { Level } \\
(-1)\end{array}$ \\
\hline A & $\begin{array}{c}\text { Part } \\
\text { Population }\end{array}$ & - & 450 & 150 \\
\hline B & Part size & $\mathrm{mm}$ & 16 & 8 \\
\hline C & $\begin{array}{c}\text { Vibration } \\
\text { frequency }\end{array}$ & $\mathrm{Hz}$ & 45 & 35 \\
\hline
\end{tabular}

Table 1. Input Parameters and their operating ranges

\subsection{Experimental design}

In this work, central composite face centered technique has been used which comprises of a total of 20 runs as per the designed matrix given in Table 2. The 20 runs consist of $\left(2^{3}+2 X 3+6=20\right) 8$ full factorial runs, 6 star points and 6 center point runs. The experiments were run in single replicate as per the design matrix combination and the response parameter, that is, feed rate for all the treatments were recorded in Table 2. The experiments were run in a random sequence to avoid any systematic errors.

\begin{tabular}{|c|c|c|c|c|c|}
\hline & & Factor 1 & Factor 2 & Factor 3 & Response 1 \\
\hline Std & Run & A:Frequency & B:Size & C:Part Population & Feed rate \\
\hline & & $\mathrm{Hz}$ & $\mathrm{mm}$ & & Parts/min. \\
\hline 14 & 1 & 0 & 0 & 1 & 76 \\
\hline 9 & 2 & -1 & 0 & 0 & 10 \\
\hline 7 & 3 & -1 & 1 & 1 & 32 \\
\hline 19 & 4 & 0 & 0 & 0 & 18 \\
\hline 5 & 5 & -1 & -1 & 1 & 286 \\
\hline 3 & 6 & -1 & 1 & -1 & 45 \\
\hline 17 & 7 & 0 & 0 & 0 & 27 \\
\hline 13 & 8 & 0 & 0 & -1 & 44 \\
\hline 11 & 9 & 0 & -1 & 0 & 264 \\
\hline 1 & 10 & -1 & -1 & -1 & 193 \\
\hline 18 & 11 & 0 & 0 & 0 & 24 \\
\hline 4 & 12 & 1 & 1 & -1 & 123 \\
\hline 16 & 13 & 0 & 0 & 0 & 20 \\
\hline 6 & 14 & 1 & -1 & 1 & 425 \\
\hline 15 & 15 & 0 & 0 & 0 & 84 \\
\hline 2 & 16 & 1 & -1 & -1 & 277 \\
\hline 20 & 17 & 0 & 0 & 0 & 19 \\
\hline 10 & 18 & 1 & 0 & 0 & 150 \\
\hline 12 & 19 & 0 & 1 & 0 & 102 \\
\hline 8 & 20 & 1 & 1 & 1 & 217 \\
\hline
\end{tabular}

Table 2. Design matrix 


\section{RESULTS AND DISCUSSIONS}

The results were analyzed by using a computer software program where adequacy of the model was tested by ANOVA (Table 3) and significance of the regression coefficients was tested by using t-tests. After dropping the insignificant terms, only the significant ones, as shown in Table 4, were included in the mathematical equation (1) which was developed for relating the response parameters to the input parameters taking into account the direct effect, curvature effect and interacting effects amongst the input parameters.
Feed Rate $=2954.82+-83.2345 * \mathrm{C}+-217.332 * \mathrm{~B}+$ $0.616121 * \mathrm{~A}+0.25 * \mathrm{C} * \mathrm{~B}+0.027 * \mathrm{C} * \mathrm{~A}+-0.0333333$ $* \mathrm{~B} * \mathrm{~A}+1.05818 * \mathrm{C} \wedge 2+8.09091 * \mathrm{~B} \wedge 2+0.000286869$ $* \mathrm{~A}^{\wedge} 2$

The Model F-value of 43.57 implies the model is significant. There is only a $0.01 \%$ chance that an Fvalue this large could occur due to noise.

P-values less than 0.0500 indicate model terms are significant. In this case $\mathrm{A}, \mathrm{B}, \mathrm{C}, \mathrm{B}^{2}$ are significant model terms. Values greater than 0.1000 indicate the model terms are not significant.

\begin{tabular}{|c|c|c|c|c|c|c|}
\hline Source & Sum of Squares & df & Mean Square & F-value & p-value & \\
\hline Model & $2.582 \mathrm{E}+05$ & 9 & 28692.57 & 43.57 & $<0.0001$ & significant \\
\hline A-Frequency & 39187.60 & 1 & 39187.60 & 59.50 & $<0.0001$ & \\
\hline B-Size & 85747.60 & 1 & 85747.60 & 130.20 & $<0.0001$ & \\
\hline C-Part Population & 12531.60 & 1 & 12531.60 & 19.03 & 0.0014 & \\
\hline AB & 200.00 & 1 & 200.00 & 0.3037 & 0.5937 & \\
\hline AC & 3280.50 & 1 & 3280.50 & 4.98 & 0.0497 & \\
\hline BC & 3200.00 & 1 & 3200.00 & 4.86 & 0.0521 & \\
\hline$A^{2}$ & 1924.57 & 1 & 1924.57 & 2.92 & 0.1182 & \\
\hline$B^{2}$ & 46085.82 & 1 & 46085.82 & 69.97 & $<0.0001$ & \\
\hline$C^{2}$ & 114.57 & 1 & 114.57 & 0.1740 & 0.6854 & \\
\hline Residual & 6586.08 & 10 & 658.61 & & & \\
\hline Lack of Fit & 3284.08 & 5 & 656.82 & 0.9946 & 0.5023 & not significant \\
\hline Pure Error & 3302.00 & 5 & 660.40 & & & \\
\hline Cor Total & $2.648 E+05$ & 19 & & & & \\
\hline
\end{tabular}

Table 3. ANOVA table for quadratic model

\begin{tabular}{|l|r|r|r|r|r|r|r|}
\hline \hline \multicolumn{1}{|c|}{ Factor } & Coefficient Estimate & df & Standard Error & $\mathbf{9 5 \%}$ CI Low & 95\% CI High & VIF \\
\hline Intercept & 40.62 & 1 & 8.82 & 20.96 & 60.28 & \\
\hline A-Frequency & 62.60 & 1 & 8.12 & 44.52 & 80.68 & 1.0000 \\
\hline B-Size & -92.60 & 1 & 8.12 & -110.68 & -74.52 & 1.0000 \\
\hline C-Part Population & 35.40 & 1 & 8.12 & 17.32 & 53.48 & 1.0000 \\
\hline AB & 5.00 & 1 & 9.07 & -15.22 & 25.22 & 1.0000 \\
\hline AC & 20.25 & 1 & 9.07 & 0.0333 & 40.47 & 1.0000 \\
\hline BC & -20.00 & 1 & 9.07 & -40.22 & 0.2167 & 1.0000 \\
\hline $\mathrm{A}^{2}$ & 26.45 & 1 & 15.48 & -8.03 & 60.94 & 1.82 \\
\hline $\mathrm{B}^{2}$ & 129.45 & 1 & 15.48 & 94.97 & 163.94 & 1.82 \\
\hline $\mathrm{C}^{2}$ & 6.45 & 1 & 15.48 & -28.03 & 40.94 & 1.82 \\
\hline \hline
\end{tabular}

Table 4. Significant coefficient terms

The curve fitting accuracy to the response surface is shown by value of $R^{2}$ in Table 5 . A value of 0.97 shows that the model sufficiently fits the response curve.

\begin{tabular}{|l|r|l|r|}
\hline \hline Std. Dev. & 25.66 & $\mathbf{R}^{\mathbf{2}}$ & 0.9751 \\
\hline Mean & 121.80 & ${\text { Adjusted } \mathbf{R}^{\mathbf{2}}}_{\mid}$ & 0.9527 \\
\hline C.V. \% & 21.07 & Predicted R $^{\mathbf{2}}$ & 0.8885 \\
\hline & & Adeq Precision & 23.3849 \\
\hline
\end{tabular}

Table 5. Fit Statistics

\subsection{Direct effects of input parameters}

The direct effects of input parameters on feed rate are shown in the perturbation graph in Figure 2.

\subsubsection{Direct effect of part population on feed rate}

From Figure 2 it is evident that the feed rate increases with the increase in part population from 150 to 450 . The probable reason for this could be that with the increase in population the availability of parts per unit time increased because of the symmetry of the parts. 


\subsubsection{Direct effect of part size on feed rate}

From Figure 2 it is evident that the feed rate first decreases and then increases with the increase in part size from 8 to $16 \mathrm{~mm}$. The probable reason for this initial decrease in feed rate could be the increased interaction between the parts whereas after a particular size the mutual interaction effects seem to reduce. In addition there could be the interactive effect of other parameters as well responsible for such behavior.

\subsubsection{Direct effect of frequency on feed rate}

From figure-2 it is evident that with the increase in frequency from 35 to $45 \mathrm{~Hz}$ there has been an increase in frequency. The probable reason for this could be that with the increase in frequency the opportunities for the parts to get on the feed track increases.

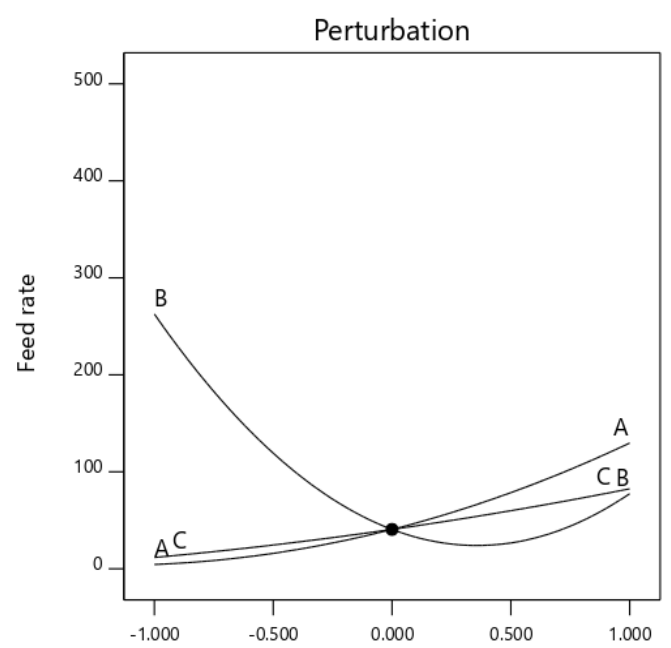

Fig. 2. Direct effects of input parameters on feed rate

\subsection{Interactive effects of input parameters on feed rate}

The mathematical model shows that there is interaction between part population and part size, part population and frequency and part size and frequency respectively. The effect of these interactions on feed rate is explained as follows:

\subsubsection{Interaction effect of part population and part size} on feed rate

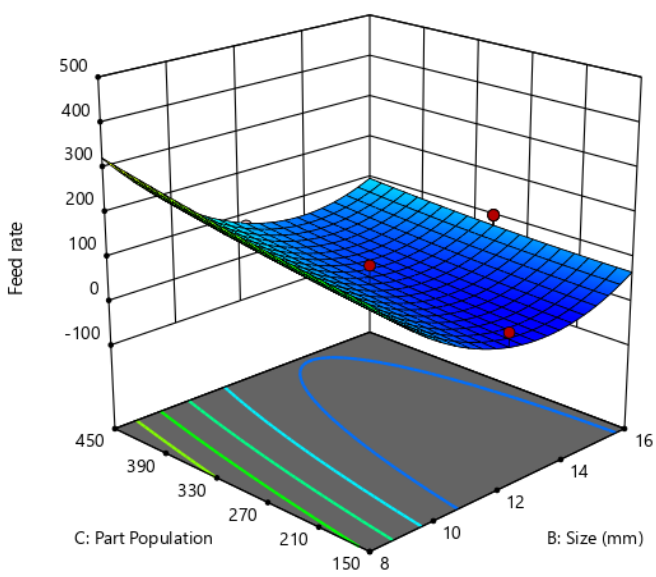

Fig. 3. Interaction effect of part population and part size on feed rate
It is evident from Figure 3 that there exist an interaction effect of part population and part size on feed rate. For all the values of part population, feed rate first decreases and then increases with the increase in part size for thr reason already mentioned. And for all values of part size feed rate increases with increase in part population. Maximum feed rate of 325 is achieved at maximum part population and minimum part size whereas a minimum feed rate of 68 is achieved at maximum part size and minimum part population.

\subsubsection{Interaction effect of part population and frequency on feed rate}

It is evident from Figure 4 that there exist an interaction effect of part population and frequency on feed rate. For all the values of part population, feed rate increases with the increase in frequency. And for all the values of frequency feed rate increases with increase in part population. Maximum feed rate of 193 is achieved at maximum part population and maximum frequency and minimum feed rate is achieved at minimum part population and minimum frequnecy.

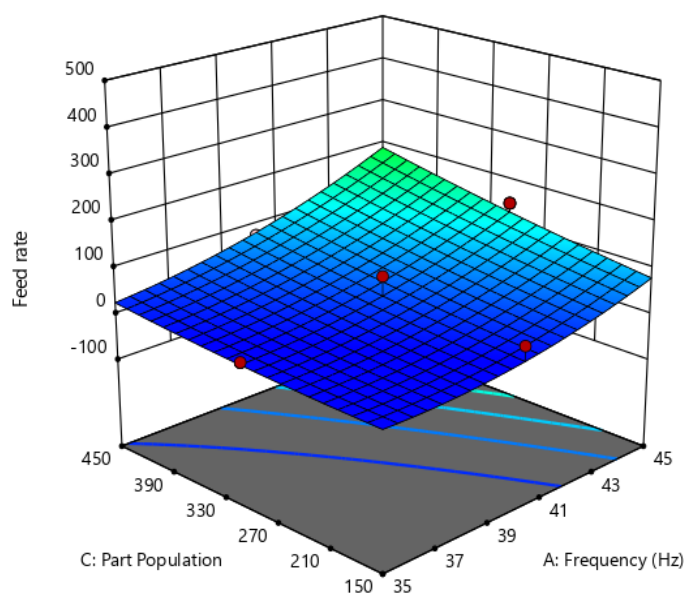

Fig. 4. Interaction effect of part population and frequency on feed rate

3.2.3 Interaction effect of part size and frequnecy on feed rate

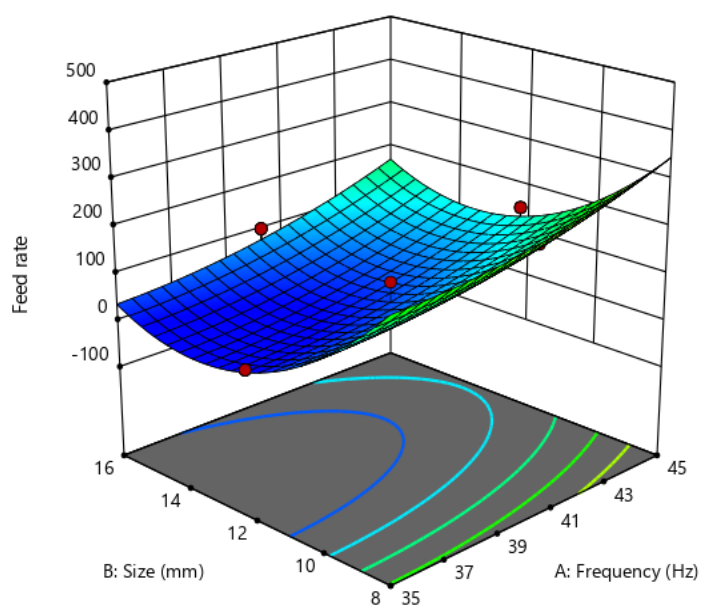

Fig. 5. Interaction effect of part size and frequency on feed rate 
It is evident from Figure 5 that there exists an interaction effect of part size and frequency on feed rate. For all values of part size, feed rate increases with the increase in frequency. And for all the values of frequency, feed rate decreases with increase in part size. Maximum feed rate of 348 is achieved at minimum part size and maximum frequency whereas a minimum feed rate of 35 is achieved at minimum frequency and maximum part size.

\subsection{Predicted vs. Actual values of the developed model}

Figure-6 shows the software generated scatter diagram plotting the predicted values on the basis of developed model and the actual values of feed rate. It is evident that both the values are in good conformance with each other. It further substantiates the significance and fitness of the developed model.

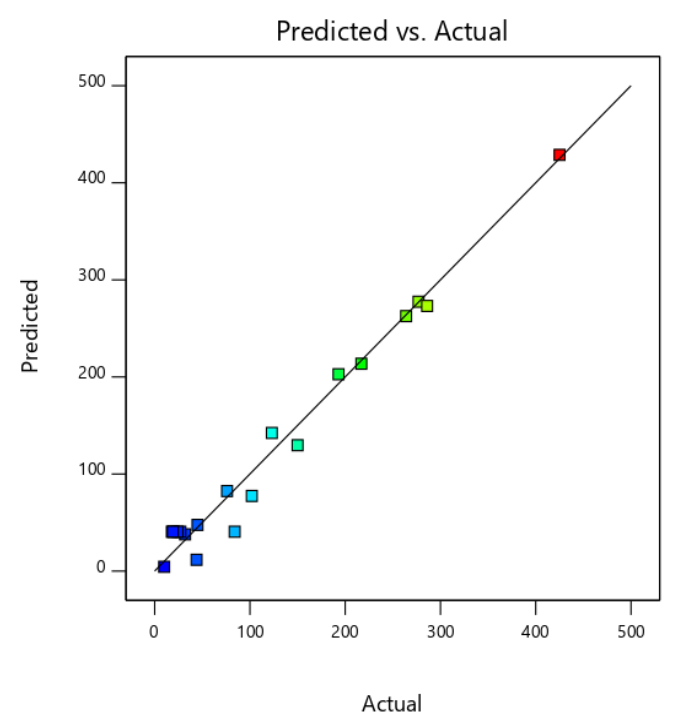

Fig. 6. Scatter diagram showing predicted vs. actual feed rate

\section{CONCLUSIONS}

It is observed that:

- The central composite face centred technique has been found satisfactory in predicting the behaviour of present feeding system

- The Design of Experiments was carried out and from the ANOVA analysis, it can be concluded that the most significant contribution to the feed rate was made by the frequency followed by the part size and finally the part population.

- The mathematical equation obtained can be used to find out the feed rate for any combination of the values of the parameters chosen.

- $\quad$ Part population and frequency have positive effect on feed rate whereas part size first has a negative effect and then a positive effect on feed rate.

- Maximum feed rate of 348 was obtained at minimum part size of $8 \mathrm{~mm}$ and maximum frequency of $45 \mathrm{~Hz}$.

Minimum feed rate of 35 was obtained at maximum part size of $16 \mathrm{~mm}$ and minimum frequency of $35 \mathrm{~Hz}$.

\section{REFERENCES}

[1] Yadav, H., Chawla, M., and Khanna, P., "Development of A Mechanical Rotary Part Feeding System with Performance Analysis”, 2017.

[2] Khanna, P., Goel, S., Anju "Design, Fabrication and Analysis of Centreboard Hopper Part Feeder”, 2008.

[3] Gupta, A., Saraf, A., Luthra, J., Gupta, N., Khanna, P., "Mathematical Modelling And Performance Analysis Of A Tumbling Barrel Hopper Feeder”, 2010.

[4] Bansal, P., Jain, A., Khanna, P., "Development of a Reciprocatory Tube Funnel Feeder and Graphical Analysis of its Performance”, 2018.

[5] Jain, A., Bansal, P., Khanna, P., “Application of Taguchi Technique to Optimize the Performance of a Vibratory Bowl Feeder”, 2017.

Authors: Anshika Jain, Student, Prachi Bansal, Student, Pradeep Khanna, Associate Prof., Division of MPAE, Netaji Subhas Institute of Technology, New Delhi-110078, India.

E-mail: prachi.bansal30@gmail.com 4.khanna@gmail.com 